TRINDADE, Eneus. Propaganda, Identidade e Discurso: Brasilidades Midiáticas. Porto Alegre: Sulinas, 2012, 191 páginas. Coleção Cena Publicitária.

\title{
UM PALIMPSESTO NO OLHAR DA COMUNICAÇÃO PARA O LIVRO PROPAGANDA, IDENTIDADE E DISCURSO: BRASILIDADES MIDIÁTICAS DE ENEUS TRINDADE.
}

Maria Angela Pavan ${ }^{1}$

\begin{abstract}
De outro lado, o humor, o cotidiano, o jeitinho brasileiro $e$ as intertextualidades que marcam os discursos estudados mostram que interdiscursividade também definidora dos elementos da identidade nacional, na medida em que tais discursos em suas redes configuram o processo histórico que caracteriza a memória discursiva das redes de subjetividades que constituem o ser nacional/brasileiro nos textos da nossa cultura. (TRINDADE, 2012:179)
\end{abstract}

Ao ler o livro de Eneus Trindade aprendemos o quanto precisamos de outras bases filosóficas e teóricas para compreender nosso lugar diante dos signos comunicacionais. Há quem diga que estamos diante de um grande mistério. Mas ao ler o livro deste pesquisador - os mistérios da comunicação se transformam em novas perspectivas de análises, lugares e reflexões.

Diante dos novos mistérios só nos resta aprender, reaprender e refletir mais. Por este motivo chamei este texto de palimpsesto, pois Eneus (a quem me refiro pelo primeiro nome como signo de amizade e admiração profissional) renova e redobra seu olhar de pesquisador e nos convida a uma profunda reflexão sobre a construção da identidade nacional na propaganda no Brasil do final do século XX na transição para o século XXI.

Muitas discussões são realizadas dentro do âmbito acadêmico, onde é praxe ouvirmos de que algumas teorias estão ultrapassadas. Em bancas acadêmicas, ouvimos quem diga que as referências estão velhas porque não fazem parte das reflexões atuais das novas mídias. Foi um grande privilégio ler um texto que nos ensina um olhar teórico, movente entre tantas teorias e filosofias para explicar a propaganda no âmbito brasileiro, aspecto este que fica esclarecido no prefácio da Profa. Dra. Clotilde Perez da

${ }^{1}$ Docente da Graduação em Comunicação e da Pós-Graduação em Estudos da Mídia na Faculdade de Comunicação Social da Universidade Federal do Rio Grande do Norte (UFRN). Participa da Base de Pesquisa PRAGMA (Pragmática da Comunicação e da Mídia: teorias, linguagens, indústrias culturais e cidadania do Decom/CCHLA/UFRN, cadastrado no CNPq). E-mail: mapavan@ cchla.ufrn.br 
Um palimpsesto no olhar da comunicação para o livro propaganda, identidade e discurso: brasilidades midiáticas de Eneus Trindade.

de Maria Angela Pavan

ECA/USP, na apresentação do autor e no capítulo 1 intitulado Identidade brasileira e publicidade: questões sobre o objeto, quando são apresentadas as linhas teóricas e empíricas do enorme trabalho que desenvolveu ao longo do mestrado e doutoramento sobre a identidade cultural brasileira e a mídia publicitária.

No capítulo 2 o autor referencia em seu texto, de forma ímpar, filósofos como Aristóteles, Heidegger e autores da semiótica e das teorias do discurso, quando o assunto é aprofundado na discussão denominada Identidade e teorias do discurso na publicidade televisiva. Neste momento do livro, Eneus trabalha os conceitos definições sobre a identidade e os relaciona com a representação da identidade cultural a partir das teorias do discurso diretamente ligadas as mensagens publicitárias televisivas.

No terceiro o título é Identidade Nacional, cidadania e consumo no Brasil. Aqui podemos perceber como é mostrada a identidade nacional para a construção da ideia de cidadania, bem como todo esse processo histórico identitário nos conecta com consumo no contexto brasileiro.

Em seguida nos apresenta sua análise de 217 mensagens publicitárias televisivas e realiza uma profunda discussão sobre identidade cultural brasileira na Era Global, e sistematiza os signos constitutivos a partir das imagens da publicidade no cotidiano, principalmente o que atravessa valores nacionais e mundiais dentro da nossa cultura com o título do quarto capítulo - O nacional versus o mundial na publicidade brasileira.

Já quinto capítulo $O$ nacional na publicidade: marketing, comunicação $e$ semiótica, por meio de um estudo teórico sobre comunicação, marketing e semiótica o autor nos mostra o processo complexo que envolve as fronteiras da comunicação, no estudo do objeto da comunicação publicitária.

E no último capítulo (sexto), A tipologia cultural brasileira nos comerciais e as considerações finais, Eneus presenteia o leitor construindo uma arquitetura de tipos identificados na publicidade e as representações, reconhecendo os limites do corpus trabalhado e as dinâmicas culturais identitárias que não permitem considerar tais tipos como totalizantes, mas sim como uma espécie de fotografia de um dado momento histórico-cultural do processo identitário brasileiro midiatizado, que pode ser inspirador ou inaugural para novas percepções. Neste capítulo de fechamento da obra também podemos observar com muita veemência um olhar transdisciplinar do pesquisador.

O pesquisaor nos ensina olhar para as imagens da propaganda com "olhos de lince". Indico o livro para os estudantes da comunicação social e também para a área de 
Um palimpsesto no olhar da comunicação para o livro propaganda, identidade e discurso: brasilidades midiáticas de Eneus Trindade.

Ciências Sociais e Humanas. O texto é riquíssimo nos desperta muita curiosidade aos símbolos televisivos da propaganda.

Como bem disse a pesquisadora Clotilde Perez no prefácio do livro, "além do estudo da identidade nacional o autor buscou entender as implicações dessas representações nos processos de significação que auxiliam, refletem e retratam estatutos identitários contemporâneos". (PEREZ in TRINDADE, 2012: 10)

O pesquisador nos remete a reflexões importantes para este momento de mudanças no estudo da comunicação e nos provoca com suas argumentações para uma perspectiva movente, pois nada é estático neste estudo da identidade e discurso. Há sempre um tempo e uma nova forma de entendimento da comunicação como bem diz o autor "no nosso estudo o ser das coisas se dá na relação com o mundo, talvez com o das mercadorias, para sermos mais precisos."

$\mathrm{O}$ autor nos oferece um livro que nos ensina um novo olhar para as propagandas do cotidiano. Ao ler sua pesquisa nos percebemos como telespectadores diante da comunicação na arquibancada da vida cotidiana.

O livro pode ser utilizado por qualquer profissional e estudante na área da comunicação, pois argumenta com diferentes autores do mundo da sociologia, antropologia, filosofia. No curso de Relações Públicas, por exemplo, os graduandos precisam aprender a ouvir os diversos públicos. Na Propaganda e Publicidade, é de suma importância desenvolver a um olhar acurado para compreender quais são as táticas e estratégias da linguagem e de quem está envolvido com a compreensão dos processos publicitários. Para o Radialista, como um profissional da difusão de informação, é muito importante estar em contato direto com os diversos espaços na sociedade. O estudante de Jornalismo ao ler o livro poderá aprender sobre o exercício de realizar uma pesquisa abrangente sobre um acontecimento ou fato histórico.

Eneus Trindade por meio de sua pesquisa mostra-nos suas inquietações na prática da pesquisa, pois sempre nos alerta que está a olhar o mundo da propaganda como uma carta náutica, que precise de acertos minuciosos para percorrer um saber.

Fica o registro da indicação de uma ótima leitura.

Artigo submetido: $15 / 11 / 2013$

Artigo aprovado: 10/12/2013. 